\title{
Rooting potential of mature stem cuttings of some for est tree species for vegetative propagation
}

\author{
E. G. Oboho* and J . N. Iyadi \\ Department of Forestry and Wildlife, Faculty of Agriculture, University of Benin, Benin City, NIGERIA \\ *Corresponding author. E-mail: esoheoboho@ hotmail.com
}

Received: September 6, 2012; Revised received:0 ctober 21, 2013; Accepted:0 ctober 25, 2013

Abstract: The growing of trees could be hindered by seed dormancy problems or unavailability of sufficient quantities of seeds, hence vegetative propagation using simple propagules like stem cuttings is a valued option especially for resource poor farmers. The rooting potential of mature stem cuttings of Gambeya albida, Irvingia gabonensis, Annona muricata, Garcinia kola and Triplochiton scleroxylon was investigated in a humid tent propagator without enhancement by artificial hormones. Propagation indicative parameters were estimated using percentages. G. kola had the highest root-ability indices with cutting survival rate of $85 \%$, callus formation $(75 \%)$, leaf loss $(35 \%)$, days to axial bud sprout ( 55 days), days to leaf loss ( 23 days) and number of new leaves produced (9) at termination of study. T.scleroxylon had no survivals; an axial bud sprouted at 51 days but withered off by the third day. Other species were between these two extremes. Root-ability potential categorization for the species on the basis of this investigation was: easy to root for: G.kola and A.muricata, moderately easy to root for I.gabonensis and G.albida, unable to root for T.scleroxylon. The use of artificial hormone, juvenile stem cutting and somatic embryogenesis trials has been suggested especially for the moderately easy and unable to root categories.

Keywords: Callus, Propagation, Root-ability, Social forestry, Stem cutting

\section{INTRODUCTION}

A forest is a renewable natural resource; an ecosystem that is dominated by trees and other wood plants (Park, 2006). It various components provide man with his needs of timber, food, fodder, fuel, medicine, building materials, household and cultural items. Forest also provides protection for man and animals as well as improving the fertility of soil. Fertility is a vital quality of soil. Soil quality or health is the foundation for all agriculture and natural plant communities and a primary indicator of sustainable land management (Doran and Zeiss, 2000). Unfortunately however, deforestation continues to threaten the survival of natural forest and its benefits to man in many parts of the world. Forest must survive to perform its usefulness to man. The sustenance of forest and its resources focuses mainly on proper management principles, sustainable utilization and conservation practices as well as effective artificial regeneration; most of which is carried out by the use of seedlings in present day Nigeria.

Seedling production relies on the use of lots of seeds needed to execute the many afforestation and reforestation programmes and seeds are not always available in the right quantity and quality for some species. Infrequent fruiting, low seed production, dormancy, attacks by pests and diseases, rapid loss of seed viability, mast year phenomenon are some causes of unavailability of adequate quantity and quality of seeds ISSN : 0974-9411 (Print), 2231-5209 (Online) All Rights Reserved ๑ Applied and Natural Science Foundation www.ansfoundation.org for sowing. Also, some trees/plants produce fruits and seeds that are food for man or wildlife; this further exacerbates the problem

Apart from the mentioned seed problems, with regards to large scale propagation and preservation of selected genetic qualities, sexual reproduction poses risks to loss of these characteristics, Henrique et al. (2006). Since the use of seed is a sexual form of reproduction, continuous use of seeds could lead to loss of some genetic characteristics in certain species. It becomes imperative that means of regeneration other than the conventional use of seeds and seedlings be explored for such problem species. Vegetative propagation is one such method worthy of attention. It is the production of new plants by asexual means (Leakey, 2004); an act of multiplying the number of plants without the use of seeds. Desired individual characteristics are maintained and the offspring is genetically identical to the original donor plant. It offers alternative opportunity for producing large quantities of planting materials from a parent stock and so could be of excellent practical use in artificial regeneration forestry just as it is important in arable crop production especially of species that do not produce seeds. Plants could be vegetatively propagated by grafting, cuttings of stem, root, leaf as well as somatic embryos (Henrique et al., 2006).

This study was set out to investigate the potential of 
vegetatively propagating some important forest tree species occurring in southern Nigeria via stem cuttings without the aid of artificial stimulation with hormones. In view of the importance of the investigated species in the livelihood of people in southern Nigeria, their ability to be naturally propagated from stem cuttings would go a long way in encouraging the planting especially of the fruit tree species and hence improve nutritional and financial wellbeing of the populace.

\section{MATERIALS AND METHODS}

Study area: The study was carried out in the arboretum of the Department of Forestry and Wildlife, Faculty of Agriculture, University of Benin, Benin City. The GPS (Global Positioning System) location is latitude $5^{0} 37^{1} \mathrm{~N}$ and longitude $6^{0} 24^{1} \mathrm{E}$, and on an altitude of $134 \mathrm{~m}$ above sea level (GPS is a system of satellites and receiving devices used to compute positions on the earth). Benin City has a temperature range of between $27^{\circ} \mathrm{C}$ to $32^{\circ} \mathrm{C}$ for most of the year, and atmospheric humidity of $75 \%$ at noon and $95 \%$ at $6.00 \mathrm{am}$. During the harmattan which occurs from the month of December to February, cold, dry and dusty North-Easterly winds bring about a considerable drop in the relative humidity. The main rainy season predominantly with South-West to West wind is from the month of May to October and the annual rainfall is 2,078mm (Master Plan, 1993).

Experimental design: The experiment was conducted in humid tent propagators according to Henrique et al (2006), Naheed et al( 2008) and Akinyele( 2010) in which temperature and humidity readings were monitored twice weekly. Stem cuttings were taken from the lateral branches of mature trees of the following species:

Gambeya albida (T. Don) Aubrev and Pellegr, Sapotaceae.

Irvingia gabonensis (Aubrey - Lecomtex O'Rorke), Irvingiacea

Annona muricata (Linn), Annonaceae.

Triplochiton scleroxylon (K. Schum),Sterculiaceae.

Each cutting was made to the length that held two nodes. They were immediately placed in a bowl of water to prevent air bubbles from entering the conducting tissues, after which they were inserted into germination trays containing washed river sand as the potting medium. Watering was done daily and observations made on propagation indicative parameters. These parameters were leaf senescence, bud sprout, new leaf formation, callus formation, root formation and survival percentage following the method used by (Adekola and Akpan, 2012). No growth hormone was used and investigation took place over a period of 133 days.

Statistical analysis: The experimental layout was in a complete randomized design (CRD) pattern. There were five species and five replications per species; each replicate having four cuttings. Least significant difference (LSD) and multiple means comparison were used to make inferences between different parameters of the species at $5 \%$ level of probability.

\section{RESULTS}

During the period of investigation, the maximum temperature inside the propagator ranged between $27^{\circ} \mathrm{C}$ to $34^{\circ} \mathrm{C}$ while the minimum ranged between $19^{\circ} \mathrm{C}$ to $23^{\circ} \mathrm{C}$. The relative humidity percent ranged from $80 \%$ to $96 \%$. The temperature inside the propagator was on the average $0.81{ }^{\circ} \mathrm{C}$ higher than the surrounding while the relative humidity was $2.25 \%$ higher.

The following developmental sequences were observed for the species namely: leaf loss, axil bud sprout, bud drying off, stem cutting death, leaf production by surviving cuttings, callus and root formation. According to Hartmann et al (1996), the order of events for a cutting to produce root is as follows: (1) Outer injured cells die (2) A necrotic plate forms and seals the wound, suberin, cork and gum block xylem. (3) Parenchyma cells (callus) form behind plate. (4) Cells near the vascular cambium divide and produce adventitious roots. Values obtained from the investigated vegetative propagation parameters have been sown on Table 1 .

L eaf loss: The time to commence the original leaf loss by T. scleroxylon was 8 days, I. gabonensis (14days), A .muricata (19 days), G . albida (23 days) and G. kola (26 days). Similarly, the time taken for all/most leaves to be lost was different with species. It was 63 days for I. gabonensis, 47 days (A .muricata) 38 days (G a albida) 28 days for $T$. scleroxylon and 23 days for $G$.kola. Only few of the leaves of $\mathrm{G}$.kola were lost.

The mean percentage leaf loss was highest for $T$. scleroxylon (100\%) A. muricata and I. gabonensis were both $90 \%$, G. albida (55\%) and G. kola was $35 \%$. There was statistical difference between species in respect of the time and percentage leaf loss.

A xial bud sprout: Axial bud sprouting for all the species (except I. gabonensis) started after the original leaves have started to drop off. That for I. gabonensis started before leaf drop.

It was first observed on the cuttings of I. gabonensis (12 days), G. kola (25 days), G. albida (31 days), A. muricata(37 days) and T. scleroxylon (51 days). Time taken for buds to sprout differed significantly with species.

New leaf formation: For three of the species namely G. albida, I. gabonensis and T. scleroxylon, after axial bud sprout, they soon dried off within days and so failed to establish leaves. Only G.kola and A. muricata produced new leaves from the axial bud sprouts. Garcinia retained (9) leaves while Annona retained (1) leaf.

Survival of cuttings: During the period of observation, 
some cuttings dried off while others remained green and alive. The survival percentages were as follows: $\mathrm{G}$. kola $(85 \%)$, G. albida $(75 \%)$ I. gabonensis $(25 \%)$ A. muricata $(15 \%)$ and $\mathrm{T}$. scleroxylon (0\%). Survival values were significantly different between species.

Callus formation: G. kola had the highest percentage of cuttings with callus formation (75\%), I. gabonensis (60\%), G. albida (20\%), T. scleroxylon (0\%). A. muricata(20\%) and also produced a visible root as well as the callus . Callus formation significantly differed with species.

\section{DISCUSSION}

The rooting potentials of the mature stem cuttings of the species examined varied greatly from one another judging from the manner of occurrence and display of propagation parameters. As a result of the early total loss of leaves and the non survival of the cuttings of T. scleroxylon in this investigation it could be said that this species cannot be vegetatively propagated from mature stem cuttings. Omagbemi (2003) recorded 50\% survival for juvenile rooted cuttings of T. scleroxylon. The difference in this study is probably due to age of cuttings. Decrease in rooting percentage of cuttings taken from older plants may be due to anatomical features such as thickening of sclerenchymatous cells which create a barrier to root initiation (Chaturvedi, 1992). I gabonensis had low stem cutting survival percentage, no new leaf formed from bud but callus formation occurred, note though that this species was the first to show bud sprout. A. muricata had low stem cutting survival but it produced buds, new leaves from buds, callus and root. G. albida on the other hand had high survival percentage of cutting, no new leaf formed from axial bud, but there was callus formation. G .kola had the highest cutting survival percentage, bud sprout, leaf formation from the bud sprouts as well as callus formation.

The best survival of cuttings was observed with G. kola and it retained most of its original leaves through out the period of investigation. Stored photosynthate in the stem cutting is essential for its physiological functioning and survival. The time taken to lose the leaf is an indication of the time that initial food material would last for. Leakey and Longman (1976) reported that leafless cuttings of T. scleroxylon had low rooting percentage when compared to that with leaf. Leaves contribute factors of importance to root initiation. Root forming substance is manufactured in the leaves and moves downwards to the base of the stem where it promotes root formation, Hartmann et al (1996) and Kroin (2009). Apart from the original leaves of the cuttings, buds in the axils of $I$. gabonensis and $T$. scleroxylon sprouted but soon withered off; only G.kola and A. muricata produced leaves from their sprouting. Stored food in the cutting is essential for sustaining sprouting and subsequent leaf formation from axillary buds.
Callus formation is a very important parameter in the test for vegetative propagation potential of a species. It is a wound healing parenchymatous tissue usually developing from the cambium, endowed with meristematic activity and useful to plants that are difficult to root. Stem cuttings of many dicotyledons will grow roots from the callus that forms over the cut surface or from the pericycle( Simon et al., 1971). According to Longman (1993) cells near the callus area reorganize to form adventitious roots and callus formation is indicative that cuttings are ready to root.

The formation of root primordium cells depends on the endogenous auxins in the cuttings and on a synergic compound such as diphenol. These substances lead to the synthesis of ribonucleic acid (RNA) which acts upon root primodium initiation (Hartmann et al., 2002). The physiological basis for the initiation of adventitious root primordia lies in the level of auxins in the tissues. Natural auxins are phytohormones produced by plants in low concentrations and regulate physiological processes in growth and development. Buds are essential for rooting as they are sources of these auxins. Leaves are auxin sources and other synergistic to auxins needed to activate root initiation are also translocated from leaves to rooting site (Hartmann et al., 1996.)

In this investigation, $G$. kola and A. muricata which had their axial buds translating to new leaves and also having callus/root formation supports the existence of positive correlation between bud and callus/root formation in cuttings and so these species are potentially rootable from mature cuttings. Natural hormones are able to enhance rooting of cuttings by their ability to convert carbohydrate reserves into soluble sugars which are necessary for cell division as well as enhancing mobilization of sugar from leaves to cutting base. I. gabonensis and $G$. albida whose axial bud sprout soon withered off were still able to produce callus and maintain modest stem survival percentage throughout the period of investigation. The buds must have produced and transferred sufficient auxins downward to the root forming points of the cuttings before withering. The callus formation by these two species is indicative of potential root-ability from their mature cuttings; probably with lesser ease than for G.kola.

\section{Conclusion}

Arising from observations regarding the survival of cuttings, sprouting of axial buds/new leaf, callus and root formation, it is evident that mature stem cuttings of $\mathrm{G}$. kola, A. muricata, G. albida and I. gabonensis have rooting abilities. Such abilities are however of varying degrees of ease. The highest rooting ability was displayed by G. kola, followed by A. muricata, I . gabonesis and G. albida in decreasing order of 

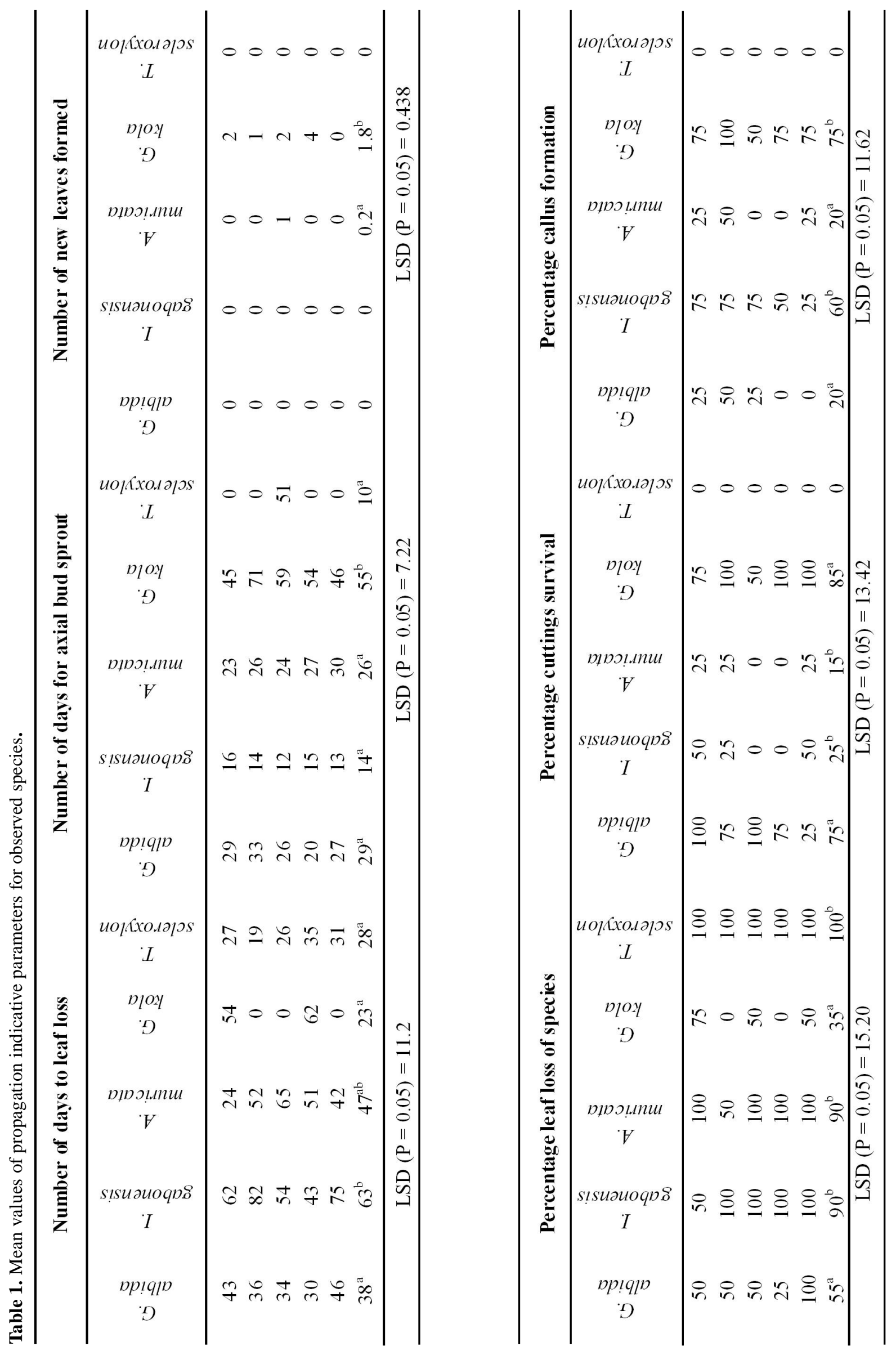
magnitude. T. scleroxylon did not show any ability to root from mature stem cuttings in this investigation. Therefore these were categorized as: easy to root for $G$. kola and A. muricata, moderately easy to root for I. gabonensis and G. albida and unable root for $T$. scleroxylon. Further researches are needed concerning rooting in these species in view of their socio-economic importance in Nigeria and their various seed problems. Artificial hormone, juvenile stem cuttings as well as somatic embryogenesis trials have been suggested especially for the moderately and unable to root categories.

\section{REFERENCES}

Adekola,O.F.and Akpan, I.G.(2012). Effects of growth hormones on sprouting and rooting of J athropha carcus I. stem cuttings. J. Applied Sci. Environ. Manage., 16 (1): 165-168.

Akinyele,A.(2010). Effects of growth hormones, rooting media and leaf size on juvenile stem cutting of Buckholzia coriacea Engler. Annals of F orest Research, 53 (2):127-133.

Chaturvedi, O. P. (1992). Vegetative propagation of Acacia auriculiformis by stem cuttings. Department of Forestry, Pajendra Agricultural University, Pusa (Samatispur), Bihar, India.

Doran, J.W. and Zeiss, M.R.(2000). Soil health and sustainability: managing the biotic component of soil quality. Applied Soil Ecol., 14:3-11.

Hartmann, H. T. and Kester, D. E., Davis, F. T. and Geneve, R. L. (1996). Plant propagation: principles and practice, $6^{\text {th }}$ ed. Prentice Hall Inc, Upper Saddle River, New Jersey, USA.

Hartmann, H. T., Kester, D. E., Davis, F. T. and Geneve, R. L. (2002). Plant propagation: principles and practices. Prentice Hall, New Jersey.
Henrique, A., Campinhos, E. N., Ono, E. O. and Zambello de Pinho, S. (2006): Effect of plant growth regulators in the rooting of Pinus cuttings. B razilian Archives of Biology and Technology, 49(2): 189-196.

Kroin, J.(2009). Plant propagation from cuttings using solutions by foliar methods. Paper presented at the International plant propagator's Society East Regional meeting, Cleveland OH. pp. 21.

Leakey, R. R. B and Longman, K. A. (1976). Root and bud formation in West African Trees. Institute of Terrestrial Ecology, Pemicuit, Scotland.

Leakey,R.R.B.(2004). Physiology of vegetative propagation. In,Burley,J., Evans,J. and Youngguist, J.A.(ed).Encyclopedia of Forest Science Academic Press, London.

Longman, K. A. (1993). Tropical trees: Propagation and planting manual. Commonwealth Science Council Technical Paper 289; London.

Master Plan (1993). Master Plan, University of Benin. University of Benin printing press. 306pp.

Naheed,G; Shahbaz,M and Akram, N.A.(2008). Interactive effect of rooting medium application of phosphorus and $\mathrm{Nacl}$ on plant biomass and mineral nutrients of rice (O ryza sativa L.) Pak. J . Bot., 40(4):1601-1608.

Omagbemi, O. B. (2003): The rooting of juvenile shoot cuttings of some timber and fruit trees. Unpublished dissertation submitted to the Department of Forestry and Wildlife, University of Benin, Benin City.

Ondra, N. J. (1998). Easy Plant propagation. Houghton Mifflin Company. Boston, New York. pp. 122

Park, C.(2006).Oxford dictionary of Environment and Conservation. Oxford University Press.Oxford. pp. 176.

Simon, E. W., Dormer, K. J. and Hartshorne, J. N. (1971). Lowson's Textbook of botany. University Tutorial Press Ltd. London. pp. 679. 